\title{
Knowledge, Attitude and Practice toward Breast Cancer among Kurdish Women in Sulaimani Governorate/ Iraq
}

\author{
Bekhal Abdalwahid Amin \\ Technical Institute in Sulaimani - \\ Sulaimani Polytechnic University, \\ Kurdistan Region, Iraq \\ kaziwanana@yahoo.com
}

\author{
Muhammed Babakir-Mina \\ Technical College of Health- \\ Sulaimani Polytechnic University \\ Kurdistan Region, Iraq \\ m.babakir@yahoo.com
}

\author{
Fadhil Ahmed Mohialdeen \\ Technical College of Health- \\ Sulaimani Polytechnic University \\ Kurdistan Region, Iraq \\ fadhilahmed@hotmail.com
}

\author{
Mohammed I M Gubari \\ Technical College of Health, \\ Sulaimani Polytechnic University \\ Kurdistan Region, Iraq \\ mohammed.gubari@spu.edu.iq
}

\begin{abstract}
Breast cancer is a devastating affliction, the frequency of which is gradually increasing all over the world. Cancer may be cured if properly intervened at the right time. The correct treatment, aided by professionals and the right technology can provide critical life support to breast cancer patients. This study was conducted to assessment knowledge, attitude and practice of breast cancer among Kurdish females visited Maternity Teaching Hospital in Sulaimani. A face-to-face interview through a question-naire to assessment of knowledge and practices toward breast cancer of 500 non-breast cancer women visited Maternity Teaching Hospital was done. Data were computerized and analyzed using Statistical Package for the Social Science (SPSS, version 22). P-value of < 0.05 was considered as statistically significant. Out of 500 participants in the current study on knowledge and practices toward breast cancer among non-breast cancer women, consequently were 227 (45.4\%) and 201 $(40.2 \%)$ practiced breast self-examination(BSE) and clinical breast examination respectively. In this study the participants having no symptoms and lack of knowledge about how to do BSE where regarded as the barriers of not practicing BSE (44.7\%, 55.3\%) respectively. The most common reason for not doing clinical breast examination (CBE) is fear of the outcome and no sign \& symptom of breast cancer $(28.8 \%, 61.9 \%)$ respectively. The high education level showed significantly more knowledge of breast selfexamination and mammography than Illiterate women $P \leq 0.001$ and $P \leq 0.03$ respectively. On the other hand, the high education level women showed significantly more practice of breast self-examination $P \leq 0.001$. In conclusion, the present study found the facts to the inadequate knowledge of female about breast cancer and recognized the negative influence of low knowledge on the practice of $B S E, C B E$ and mammography and the breast cancer incidence. Therefore, more determinations are needed to develop $a$ positive attitude toward $B S E, C B E$ and mammography screening and practice in Sulaimani.
\end{abstract}

Keywords: Knowledge, Attitude, Practice, Breast Cancer, Kurdish Women, Sulaimani.

\section{INTRODUCTION}

Breast cancer is a major health burden in women; it is the most common cause of cancer death among women in both high recourse and low recourse countries [1]. The incidence, mortality and survival rate in different parts of the world vary from 4 to 10 fold. Recent global cancer statistics indicate that breast cancer incidence is rising at a faster rate in populations in developing countries [2, 3]. The primary risk factors for breast cancer are: genetic susceptibility, increasing age, family history, early menarche and late menopause, oral contraceptive pills, postmenopausal hormone therapy, late first pregnancy (30 years or older), lack of breastfeeding, smoking, alcohol consumption, and obstetric history [4,5]. Delayed presentation of breast cancer is associated with lower survival rate [6], moreover the late stage of disease and high mortality are seen with delayed in diagnosis and treatment of breast cancer [7]. There is data suggesting that, factors related to women's knowledge and beliefs about breast cancer and its management may contribute significantly to medical help- seeking behaviors [8,9]. The three screening methods recommended for breast cancer includes breast self-examination (BSE), clinical breast examination (CBE), and mammography. Unlike CBE and mammography, which require hospital visit and specialized equipment's and expertise, the breast selfexamination is inexpensive and is carried out by the women's themselves. Several studies, based on breast cancer patient's retrospective self-report on their practices of the exam, have established that a positive association exists between performance of the exam and early detection of breast cancer [10]. There are many studies in the world showed that lack knowledge and practice about breast cancer lead to delayed presentation, on the diagnosis and treatment of the disease with lower survival rate [6,7], therefor increasing knowledge and practice toward breast cancer is very important among the individuals to decrease the incidence and increase early detection of the disease. Therefore the role of education and knowledge in decreasing delayed presentation and diagnosis has been confirmed in other study $[11,12]$. So the study aimed to assess knowledge, attitude and practice toward breast cancer among Kurdish females.

\section{METHODS AND MATERIALS}

The cross sectional study, was conducted on 500 Kurdish Women in Sulaimani Governorate/Iraq aged from 20-74 years who attended to Maternity Teaching Hospital in Sulaimani from the $20^{\text {th }}$ of December to $20^{\text {th }}$ July 2016. The method of selection sampling was convenient sampling method.

Inclusion criteria

-Females with non -breast cancer aged between 20-74 years.

-Only population of the Sulaimani and it's surrounding. 
-Only the Kurdish populations were included.

Exclusion criteria

-Females under 20 years old.

-Females with breast cancer and other types of cancer.

-Non Kurdish Females.

-Females out of Sulaimani-governorate.

A face-to- face interview through a questionnaire with non- breast cancer females who visited Sulaimani Maternity Teaching Hospital. Verbal consent was taken from women, after disclosure statement regarding the purpose of the study. Data were collected during the period of study. The questionnaire was consisted of two main parts: Part one: socio-demographic characteristics of the study sample. Part two: questions related to knowledge, attitude and practices. The data were collected and tabulated. The recorded data were analyzed using computer based statistical package for social science (SPSS, V.22). Simple descriptive statistics were used (frequency with percentage distribution for categorized variables). Chi-square cross tabulation was used to test the differences to get the association in proportions of categorical variable between two or more groups and assess/find correlation between the variables. The level of statistical significance was set at probability $\mathrm{P} \leq 0.05$.

\section{RESULTS}

The study includes 500 participant females, were visited maternity teaching hospital.

Table 1. Showed the socio-demographic characteristics of the participants. The age of the studied female ranged from 20 to 74 years with a mean \pm SD of $(35.9 \pm 8.96)$ years. Majority of participants 223 (44.6\%), were between 31to 40 years of age .467 (93.4\%) were married. The majority of the participants $174(34.8 \%)$ of them were High education level. Regarded occupational status of the participants majority of the participants were house wife $299(59.8 \%)$. Regarding marital status, $469(93.4 \%)$ of participants were married. In addition, from 500 participants $390(78 \%)$ were with urban residency and $110(22 \%)$ of participants had rural residency.

When we asked the participants about the risk factors for the breast cancer in table $2(80.2 \%)$ indicated that positive family history was the common risk factor while $(75.5 \%)$ and $(70 \%)$ demonstrated that smoking and alcohol consumption respectively.

Table 3. When we asked the participant about the knowledge toward the signs \& symptoms of breast cancer $380(76.0 \%), 370(74 \%)$ and 366(73.2) indicated that lump in the breast, Discoloration/ dimpling of the breast and Change in the size of the breast were the common signs of breast cancer respectively.

\begin{tabular}{lll}
$\begin{array}{l}\text { Table1.Demographical } \\
\text { participants (No.=500) }\end{array}$ & characteristics of the \\
\hline Characteristics & No. & $(\%)$
\end{tabular}

Age (years)

$\begin{array}{ll}20-30 & 137 \\ 31-40 & 223 \\ 41-50 & 105 \\ 51-60 & 28 \\ \text { Above 60 } & 7\end{array}$

Education

$\begin{array}{ll}\text { Illiterate } & 127 \\ \text { Primary } & 108 \\ \text { Secondary } & 91 \\ \text { High education } & 174\end{array}$

Occupation

$\begin{array}{lr}\text { House wife } & 299 \\ \text { Student } & 25 \\ \text { Employer } & 176\end{array}$

Marital status

$\begin{array}{ll}\text { Married } & 467 \\ \text { Unmarried } & 33\end{array}$

Residence

$\begin{array}{ll}\text { Urban } & 390 \\ \text { Rural } & 110\end{array}$

Total

500

As illustrated in Table 4. 175 (35.0\%) of the participants were confirmed the breast self-examination (BSE) usefulness in early detection of breast cancer. On the other hand, 228 (45.6\%) participants were confirmed the clinical breast examination (CBE) usefulness in early detection of breast cancer. Only $22(4.4 \%)$ confirmed mammography usefulness in early detection; however, only $112(22.4 \%)$ of the participants had knowledge of the correct age for screening mammography. In addition, $199(39.8 \%)$ of the participants recognized the correct BSE frequency.

As illustrated in table 5. When we asked the participants about the practice of breast self examination (BSE), out of 500 participants, only 227 $(45.4 \%)$ were practiced breast self-examination, while only $74(32.5 \%)$ identified the correct time for practice of breast self-examination. In addition 54 (23.8\%) of the participants recognized the correct age for starting breast self-examination, on the other hand when we asked 
about the reasons for not practicing breast selfexamination the highest percentage of chosen barrier 151 $(55.3 \%)$ was "I don't know how to do that" and followed by 122 (44.7\%) "I don't have breast problem".

As illustrated in table 6. When we asked the participants about the practice of clinical breast examination (CBE) Out of 500 participants only 201 $(40.2 \%)$ were admitted clinical breast examination (CBE), $121(60.2 \%)$ of the participants visited breast clinics only one time, $57(28.4 \%)$ and $23(11.4 \%)$ of the participants visited breast clinics 2-3 time and 3-5 time respectively. Consequently, when we asked about the reasons for not going through consulting clinical breast examination, the highest percentage of chosen barrier $185(61.9 \%)$ was "I don't have sign and symptom" followed by $86.0(28.8 \%)$ "Fear of outcome".

As showed in Tables 7. The knowledge of breast selfexamination as a method of early detection was higher in the age group (31-40) (40\%), compared to the other age group (20-30) (31.4\%), (41-50) (20.6\%), (51-60) (7.4\%), and above $60(0.6 \%)$ respectively. However, this difference was statistically not significant. Regarding the level of education the knowledge of participants toward breast self-examination was higher among highly education level 96 (54.9\%), compared to the other level of education illiterate, primary level and secondary level were $21(12.0 \%) . \quad 31 \quad(17.7 \%)$ and $27 \quad(15.4 \%)$ respectively. However, this difference was statistically significant $p \leq 0.001$. About the knowledge of participants toward breast self-examination was higher among married women 165 (94.3\%), compared to the unmarried $10(5.7 \%)$ and this difference was statistically not significant.

As illustrated in Tables 8. The knowledge of clinical breast-examination as a method of early detection was higher in the age group (31-40) (50.4\%), compared to the other age group (20-30) (28.2\%), (41-50) (16.2\%), (51-60) (4.8\%), and above $60(0.4 \%)$ respectively, and this difference was statistically significant $\mathrm{p} \leq 0.02$. Regarding the level of education; the knowledge of participants toward clinical breast--examination was higher among higher education level 75 (32.9\%), compared to the other level of education illiterate, primary level and secondary level 68(29.8\%). 47 $(20.6 \%)$ and $38(16.7 \%)$ respectively. However, this difference was not statistically significant. The knowledge of participants toward clinical breastexamination was higher among married women 212 $(93 \%)$, compared to the unmarried $16(7.0 \%)$ and this difference was statistically not significant.

As showed in Tables 9. The knowledge of mammography as a method of early detection was higher in the age group (41-50) (50\%), compared to the other age group (20-30) (18.2\%), (31-40) (22.7\%), (5160) $(9.1 \%)$, and above $60(0 \%)$ respectively . However, this difference was statistically not significant. Regarding the level of education the knowledge of participants toward mammography was higher among high education level 14 (63.6\%), compared to the other level of education illiterate, primary level and secondary level 3(13.6\%). $2(9.2 \%)$ and $3(13.6 \%)$ respectively. However, this difference was statistically significant $p \leq 0.03$. About the knowledge of participants toward mammography was higher among married women 21 $(95.5 \%)$, compared to the unmarried $1.0(4.5 \%)$ and this difference was statistically not significant.

Table2.Information about the breast cancer risk factors identified by the participants(No.=500)

\begin{tabular}{|c|c|c|}
\hline Risk factors & No. & $(\%)$ \\
\hline \multicolumn{3}{|l|}{ Increase age } \\
\hline Yes & 198 & (39.6) \\
\hline No & 302 & $(60.0)$ \\
\hline $\begin{array}{l}\text { Positive } \\
\text { history }\end{array}$ & \multicolumn{2}{|c|}{ family } \\
\hline Yes & 401 & $(80.2)$ \\
\hline No & 99 & $(19.8)$ \\
\hline \multicolumn{3}{|l|}{ High fat diet } \\
\hline Yes & 318 & $(63.6)$ \\
\hline No & 182 & $(36.4)$ \\
\hline \multicolumn{3}{|l|}{ Smoking } \\
\hline Yes & 377 & $(75.4)$ \\
\hline No & 123 & $(24.6)$ \\
\hline \multicolumn{3}{|c|}{ Alcohol consumption } \\
\hline Yes & 350 & $(70.0)$ \\
\hline No & 150 & $(30.0)$ \\
\hline \multicolumn{3}{|c|}{ Late first pregnancy } \\
\hline Yes & 269 & $(53.8)$ \\
\hline No & 231 & $(46.2)$ \\
\hline \multicolumn{3}{|c|}{ Early menarche } \\
\hline Yes & 112 & $(22.4)$ \\
\hline No & 388 & $(77.6)$ \\
\hline \multicolumn{3}{|c|}{ Late menopause } \\
\hline Yes & 207 & $(41.4)$ \\
\hline No & 293 & $(58.6)$ \\
\hline \multicolumn{3}{|l|}{ Stress } \\
\hline Yes & 230 & $(46.0)$ \\
\hline No & 270 & $(54.0)$ \\
\hline \multicolumn{3}{|c|}{ Large breasts } \\
\hline Yes & 166 & $(33.2)$ \\
\hline No & 334 & $(66.8)$ \\
\hline Total & 500 & $(100)$ \\
\hline
\end{tabular}

As illustrated in table 10, The practice of breast selfexamination was higher in the age group (31-40) (42.7\%), compare to the other age group (20-30) $(26.9 \%),(41-50)(20.7 \%),(51-60)(7.1 \%)$, and above 60 $(2.6 \%)$ respectively. However, this difference was statistically not significant. Regarding the level of education, the practice of breast self-examination was higher among higher education level 102 (44.9\%), compared to the other level of education illiterate, primary level and secondary level 43(18.9\%), 46 $(20.3 \%)$ and $36(15.9 \%)$ respectively. However, the association was statistically significant $p \leq 0.001$. About the practice toward breast self-examination was higher 
among married women 211 (93\%), compared to the unmarried $16(7.0 \%)$ and this difference was statistically not significant.

Table3.Information about the sign \& symptoms of Breast cancer as identified by the participants(No.=500)

\begin{tabular}{lll}
\hline Sign \& symptoms & No. & $(\%)$ \\
\hline
\end{tabular}

Lump in the breast

$\begin{array}{lll}\text { Yes } & 380 & (76.0) \\ \text { No } & 120 & (24.0)\end{array}$

Discharge from the (24.0)

nipple

$\begin{array}{lll}\text { Yes } & 266 & (53.2) \\ \text { No } & 234 & (46.8)\end{array}$

Pain and soreness in the breast

$\begin{array}{lll}\text { Yes } & 310 & (62.0) \\ \text { No } & 190\end{array}$

Change in the size of the breast

$\begin{array}{lll}\text { Yes } & 366 & (73.2) \\ \text { No } & 134 & (26.8)\end{array}$

Discoloration/ dimpling of the breast

$\begin{array}{lll}\text { Yes } & 370 & (74.0) \\ \text { No } & 130 & (26.0)\end{array}$

Ulceration of the breastlnipple

$\begin{array}{lll}\text { Yes } & 358 & (71.6) \\ \text { No } & 142 & (28.4) \\ \text { loss } & & \\ \text { Yes } & 313 & (62.6) \\ \text { No } & 187 & (37.4)\end{array}$

Changes in the shape of the breast

$\begin{array}{lll}\text { Yes } & 349 & (69.8) \\ \text { No } & 151 & (30.2) \\ \text { Yn retraction } & & \\ \text { Yes } & 347 & (69.4) \\ \text { No } & 153 & (30.6) \\ \text { under armpit } & & \\ \text { Yes } & 305 & (61.0) \\ \text { No } & 195 & (39.0)\end{array}$

Scaling/ dry skin in nipple region

$\begin{array}{lll}\text { Yes } & 243 & (48.6) \\ \text { No } & 257 & (51.4) \\ & 500 & (100)\end{array}$

Total 500

As shown in Tables 11. The practice of clinical breastexamination was higher among the age group (31-40) (45.8\%), compared to the other age group (20-30) (23.9\%), (41-50) (23.4\%), (51-60) (6.5\%), and above 60 $(0.5 \%)$ respectively, however, this difference was statistically not significant $\mathrm{p}=0.3$. Regarding the level of education; the practice toward clinical breast-examination was higher among higher educated level 62 $(30.8 \%)$, compared to the other level of education illiterate, primary level and secondary level 45(22.4\%). $51(25.4 \%)$ and $43(21.4 \%)$ respectively. However, this difference was statistically not significant $\mathrm{p}=0.1$. About the practice toward clinical breast-examination was higher among marred women 189 (94\%), compare to the unmarred $12(6.0 \%)$ and this difference was statistically not significant.

Table 4. Knowledge about method of early detection of breast cancer identified by the participants(No.=500)

\begin{tabular}{lcc}
\hline Method & No. & $(\%)$ \\
\hline breast self- examination(BSE) & \\
Yes & 175 & $(35.0)$ \\
No & 325 & $(65.0)$
\end{tabular}

Do you know at which age breast self- examination should be started

$\begin{array}{lll}\text { Yes } & 369 & (73.8) \\ \text { No } & 131 & (26.2)\end{array}$

Do you know how to perform self-breast examination

Yes $\quad 300$

No 200

Do you know how often breast self- examination should be done

$\begin{array}{lll}\text { Daily } & 16 & (3.2) \\ \text { Weekly } & 102 & (20.4) \\ \text { Monthly } & 199 & (39.8) \\ \text { Don't know } & 183 & (36.6) \\ \text { Clinical breast examination (CBE) } \\ \text { Yes } & 228 & \\ \text { No } & 272 & \text { (54.6) }\end{array}$

Do you know how often CBE should be done until a women reach 40 years

$\begin{array}{ll}\text { Once in a year } & 466 \\ \text { Once in two years } & 4 \\ \text { Once in three years } & 1 \\ \text { Don't know } & 29 \\ \text { Ultra sound } & \\ \text { Yes } & 36 \\ \text { No } & 464 \\ \text { Mammography } & \\ \text { Yes } & 22 \\ \text { No } & 478\end{array}$

Do you know recommended age for mammography examination to start

$\begin{array}{ll}\text { At the age of } 30 & 107 \\ \text { At } 35 & 87 \\ \text { At } 40 & 112 \\ \text { At } 45 & 33 \\ \text { Don't know } & 161\end{array}$


Table 5.Practice of breast self examination $\left(\mathrm{No}_{\mathbf{2}}=\mathbf{5 0 0}\right)$

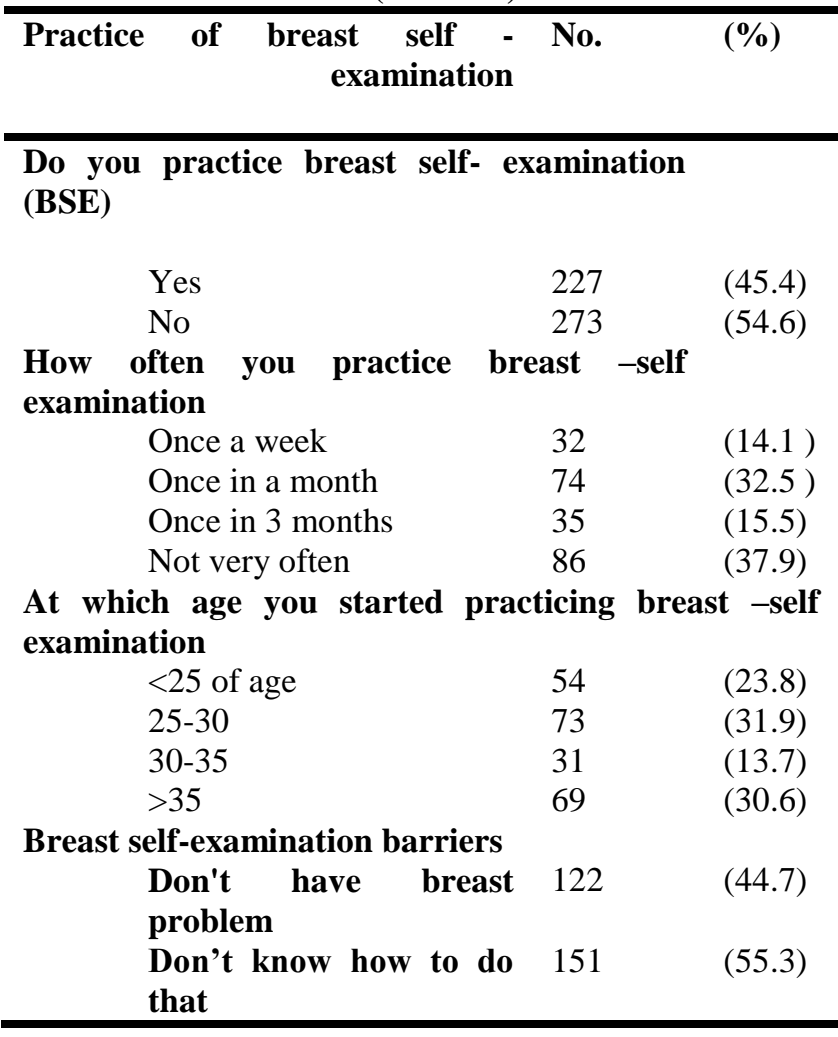

Table 6. Information about practice of Clinical breast examination (CBE)(No.=500)

\begin{tabular}{|c|c|c|}
\hline \multicolumn{2}{|c|}{$\begin{array}{l}\text { Clinical breast examination (CBE) } \\
\text { No. }\end{array}$} & $(\%)$ \\
\hline Yes & 201 & $(40.2)$ \\
\hline No & 299 & (59.8) \\
\hline \multicolumn{3}{|c|}{$\begin{array}{l}\text { Frequency of clinical } \\
\text { breast examination }\end{array}$} \\
\hline Once & 221 & $(60.2)$ \\
\hline 2-3 times & 57 & (28.4) \\
\hline 3-5 times & 23 & (11.4) \\
\hline
\end{tabular}

Why do you reluctant to participate in Clinical breast examination (CBE)

\begin{tabular}{lll}
-Concern about extra & 3 & $(1.0)$ \\
money & & \\
-Concern about extra time & 10 & $(3.3)$ \\
-Fear of outcome & 86 & $(28.8)$ \\
-Too young to participate & 11 & $(3.7)$ \\
-No signs \& symptoms of & 185 & $(61.9)$ \\
breast cancer & & \\
-No one recommended & 4 & $(1.3)$ \\
\hline
\end{tabular}

Table 7 .Knowledge of breast self-examination (BSE) as a method of early detection, according to Age, Education level and Marital status.

\begin{tabular}{|c|c|c|c|c|c|}
\hline \multirow{2}{*}{$\begin{array}{l}\text { BSE } \\
\text { Characteristics }\end{array}$} & \multicolumn{2}{|c|}{$\begin{array}{l}\text { Yes } \\
(\text { No.=175) }\end{array}$} & \multicolumn{2}{|c|}{$\begin{array}{l}\text { No } \\
(\text { No.=325) }\end{array}$} & \multirow[t]{2}{*}{$\begin{array}{l}\text { (p } \\
\text { value) }\end{array}$} \\
\hline & NO. & $(\%)$ & No. & $(\%)$ & \\
\hline \multicolumn{6}{|l|}{ Age (years) } \\
\hline $20-30$ & 55 & (31.4) & 82 & $(25.2)$ & \\
\hline $31-40$ & 70 & $(40.0)$ & 153 & $(47.1)$ & \\
\hline $41-50$ & 36 & (20.6) & 69 & (21.3) & $(0.2)$ \\
\hline $51-60$ & 13 & (7.4) & 15 & (4.6) & \\
\hline Above 60 & 1 & $(0.6)$ & 6 & (1.8) & \\
\hline \multicolumn{6}{|l|}{ Education } \\
\hline Illiterate & 21 & (12.0) & 106 & (32.6) & \\
\hline Primary & 31 & (17.7) & 77 & (23.7) & \\
\hline Secondary & 27 & (15.4) & 64 & (19.7) & \\
\hline $\begin{array}{l}\text { High } \\
\text { education }\end{array}$ & 96 & (54.9) & 78 & $(24.0)$ & $(0.001)^{*}$ \\
\hline \multicolumn{6}{|l|}{ Marital status } \\
\hline Married & 165 & (94.3) & 302 & (92.9) & \\
\hline Unmarried & 10 & (5.7) & 23 & (7.1) & $(0.5)$ \\
\hline
\end{tabular}

Table 8. Knowledge of clinical breast examination (CBE) as a method of early detection, according to Age, Education level and Marital status.

\begin{tabular}{|c|c|c|c|c|c|}
\hline \multirow{2}{*}{$\begin{array}{l}\text { CBE } \\
\text { Characteristics }\end{array}$} & \multicolumn{2}{|c|}{$\begin{array}{l}\text { Yes } \\
(\text { No.=228) }\end{array}$} & \multicolumn{2}{|c|}{$\begin{array}{l}\text { No } \\
\text { (No.=(272) }\end{array}$} & \multirow[t]{2}{*}{$\begin{array}{l}\text { (p } \\
\text { value) }\end{array}$} \\
\hline & NO. & $(\%)$ & No. & $(\%)$ & \\
\hline \multicolumn{6}{|l|}{ Age (years) } \\
\hline $20-30$ & 64 & $(28.2)$ & 73 & $(26.8)$ & \multirow{5}{*}{$(\mathbf{0 . 0 2})^{*}$} \\
\hline $31-40$ & 115 & $(50.4)$ & 108 & (39.7) & \\
\hline $41-50$ & 37 & $(16.2)$ & 68 & $(25.0)$ & \\
\hline $51-60$ & 11 & (4.8) & 17 & (6.3) & \\
\hline Above 60 & 1 & $(0.4)$ & 6 & $(2.2)$ & \\
\hline \multicolumn{6}{|l|}{ Education } \\
\hline Illiterate & 68 & $\begin{array}{l}( \\
29.8)\end{array}$ & 59 & $\begin{array}{l}( \\
21.7)\end{array}$ & \multirow{4}{*}{$(0.2)$} \\
\hline Primary & 47 & (20.6) & 61 & (22.4) & \\
\hline Secondary & 38 & (16.7) & 53 & $(19.5)$ & \\
\hline $\begin{array}{l}\text { High } \\
\text { education }\end{array}$ & 75 & (32.9) & 99 & (36.4) & \\
\hline \multicolumn{6}{|l|}{ Marital status } \\
\hline Married & 212 & $(93.0)$ & 255 & $(93.7)$ & \\
\hline Unmarried & 16 & (7.0) & 17 & (6.3) & $(0.7)$ \\
\hline
\end{tabular}


Table9. Knowledge of mammography as a method of early detection of breast cancer according to Age, Education level and Marital status

Table11. Practice of clinical breast examination CBE, according to the Age, Education level and Marital status

\begin{tabular}{|c|c|c|c|c|c|c|c|c|c|c|c|}
\hline \multirow{2}{*}{$\begin{array}{l}\text { Mammography } \\
\text { characteristics }\end{array}$} & \multicolumn{2}{|c|}{$\begin{array}{l}\text { Yes } \\
(\text { No.=22) }\end{array}$} & \multicolumn{2}{|c|}{$\begin{array}{l}\text { No } \\
\text { (No.=478) }\end{array}$} & \multirow[t]{2}{*}{$\begin{array}{l}\text { (p } \\
\text { value) }\end{array}$} & \multirow[t]{2}{*}{$\begin{array}{l}\text { CBE } \\
\text { Characteristics }\end{array}$} & \multicolumn{2}{|c|}{$\begin{array}{l}\text { Yes } \\
(\mathrm{N} 0 .=201)\end{array}$} & \multicolumn{2}{|c|}{$\begin{array}{l}\text { No } \\
\text { (N0.=299) }\end{array}$} & \multirow[t]{2}{*}{$\begin{array}{l}\text { (p } \\
\text { value) }\end{array}$} \\
\hline & No. & $(\%)$ & No. & $(\%)$ & & & NO. & $(\%)$ & NO. & $(\%)$ & \\
\hline Age (years) & & & & & & Age (years) & & & & & \\
\hline $20-30$ & 4 & ( & 133 & $(27.8)$ & & $20-30$ & 48 & $(23.9)$ & 89 & $(29.8)$ & \\
\hline & & 18.2) & & & & $31-40$ & 92 & $(45.8)$ & 130 & $(43.5)$ & \\
\hline $31-40$ & 5 & $(22.7)$ & 218 & $(45.6)$ & & $41-50$ & 47 & (23.4) & 59 & (19.7) & $(0.3)$ \\
\hline $41-50$ & 11 & $(50.0)$ & 94 & (19.7) & $(0.1)$ & $51-60$ & 13 & $(6.5)$ & 15 & $(5.0)$ & \\
\hline $51-60$ & 2 & $(9.1)$ & 26 & $(5.4)$ & & Above 60 & 1 & $(0.5)$ & 6 & (2.0) & \\
\hline Above 60 & 0 & $(0.0)$ & 7 & (1.5) & & Education & & & & & \\
\hline Education & & & & & & Illiterate & 45 & $(22.4)$ & 81 & $(27.1)$ & \\
\hline Illiterate & 3 & $(13.6)$ & 124 & $(25.9)$ & & Primary & 51 & $(25.4)$ & 58 & (19.4) & \\
\hline Primary & 2 & $(9.2)$ & 106 & $(22.2)$ & & Secondary & 43 & (21.4) & 48 & (16.1) & $(0.1)$ \\
\hline Secondary & 3 & (13.6) & 88 & (18.4) & & High & 62 & (30.8) & 112 & $(37.5)$ & \\
\hline High & 14 & & 160 & $(33.5)$ & $(0.03)^{*}$ & education & & & & & \\
\hline education & & 63.6) & & & & Marital status & & & & & \\
\hline Marital status & & & & & & Married & 189 & $(94.0)$ & 278 & $(93.0)$ & \\
\hline Married & 21 & $(95.5)$ & 446 & (93.3) & & Unmarried & 12 & $(6.0)$ & 21 & $(7.0)$ & $(0.6)$ \\
\hline Unmarried & 1 & $(4.5)$ & 32 & $(6.7)$ & $(0.6)$ & & & & & & \\
\hline
\end{tabular}

Table 10 .Practice of breast self-examination BSE according to Age, Education level and Marital status

\begin{tabular}{|c|c|c|c|c|c|}
\hline $\begin{array}{l}\text { BSE } \\
\text { characteristics }\end{array}$ & \multicolumn{2}{|c|}{$\begin{array}{l}\text { Yes } \\
(\text { No.=227) }\end{array}$} & \multicolumn{2}{|c|}{$\begin{array}{l}\text { No } \\
(\text { No.=273) }\end{array}$} & $\begin{array}{l}\text { (p } \\
\text { value) }\end{array}$ \\
\hline \multicolumn{6}{|l|}{ Age (years) } \\
\hline $20-30$ & 61 & $(26.9)$ & 76 & $(27.8)$ & \\
\hline $31-40$ & 97 & $(42.7)$ & 126 & $(46.2)$ & \\
\hline $41-50$ & 47 & (20.7) & 58 & $(21.2)$ & (0.1) \\
\hline $51-60$ & 16 & $(7.1)$ & 12 & $(4.4)$ & \\
\hline Above 60 & 6 & $(2.6)$ & 1 & $(0.4)$ & \\
\hline \multicolumn{6}{|l|}{ Education } \\
\hline Illiterate & 43 & (18.9) & 84 & $(30.8)$ & \\
\hline Primary & 46 & (20.3) & 62 & $(22.7)$ & \\
\hline Secondary & 36 & (15.9) & 55 & $(20.1)$ & \\
\hline $\begin{array}{l}\text { High } \\
\text { education }\end{array}$ & 102 & $(44.9)$ & 72 & $(26.4)$ & $(0.001)^{*}$ \\
\hline \multicolumn{6}{|l|}{ Marital status } \\
\hline Married & 211 & $(93.0)$ & 256 & $(93.4)$ & \\
\hline Unmarried & 16 & $(7.0)$ & 17 & $(6.6)$ & $(0.204)$ \\
\hline
\end{tabular}

\section{DISCUSSION}

4.1. Knowledge and practice toward breast cancer The present study results showed that the majority of the participants were in age between (31-40) years old, 93.4\% of participants were married; this high percentage of marriage was assigned to socio-demographic factors as Islamic culture trend for early marriage and economic state (Table1). This finding is nearly in accordance to the previous cross sectional study that design among female aged more than 19 years in Mosul city, Iraq (both rural and urban) in 1996 which show that $92.5 \%$ of the sample were married [13], our' result was consistent with study done among adult Saudi women [14]. Regarding the associated risk factors for breast cancer, about $80.2 \%$

of the participants knew that positive family history is the risk factors of breast cancer (Table2), other study conducted in Nigeria have also reported similar finding where that study have presented that the incidence of breast cancer is to be slightly higher in persons that have first degree relatives with a history of breast cancer [15]. In our study $75.4 \%$ of the participants said that smoking is a risk factors of breast cancer (Table2), these results were similar to that reported in a study done in Lagos where that study had presented that the incidence of breast cancer is to be slightly higher in persons that had history of smoking [16]. While $63.6 \%$ knew that high fat diet also an implicated risk factor (Table2), this is consistent by several studies conducted in Nigeria $[15,16]$, previous studies have presented that the incidence was also increased with increasing age of the patient, obesity, physical inactivity, radiation exposure, intake of alcohol and high fat. Most of the participants in our study didn't know the association between breast cancers and increasing age $39.6 \%$, early menarche $22.4 \%$ and large breast $33.2 \%$ (Table 2 ), contrary to that other studies conducted in Nigeria presented that the incidence of breast cancer is also increased with increasing age of the patient and early menarche [16]. Also, around $70.0 \%, 53.8 \%$ and $41.4 \%$ of participants realized the effect of alcohol consumption, delivery of first child after the age 30 and late menopause respectively were risk factors of breast cancer (Table2), our results are similar with the study conducted in Nigeria [17]. The result of our study showed that the participants have poor understanding of major breast cancer risk factors, may be due to poor knowledge, some of breast cancer risk factors can be changed with health education [18]. In the present study, $76.0 \%$ of the studied population knew that a breast lump could be a warning sign of breast cancer (Table8). In another study among a Nigerian population, only $33 \%$ of population 
identified that a breast lump is the commonest symptom of breast cancer [19]. Contrary to that, other researchers conducted in Jordanian established that the warning signs of breast cancer (e.g., painless lump, nipple retraction, bloody discharge from the nipple) were not well known among their participant women [20]. In the current study, 53.2\% participants answered correctly when they asked about bloody discharge from nipple and $74.0 \%$ about change in breast skin(discoloration/dimpling of breast ) (Table3), Other studies conducted in Nigeria women have also reported similar findings [21]. In our study only $38.0 \%$ of the participants said that pain and soreness in the breast are not signs of breast cancer (Table 3), this luck of information may be due to poor knowledge about symptoms of breast cancer. Whereas in another study conducted in Iran only $27 \%$ said that pain is not a sign of breast cancer [22]. These wrong information's or assumptions about breast lumps may account for some of the reasons why some of our patients present late to the hospital [23]. The current study showed that 35\% and $45.6 \%$ of the participants were informed about breast self-examination (BSE) as well as clinical breastexamination (CBE) respectively and little about mammography $4.4 \%$ (Table4). The high educational level was variable found to have a significant correlation $(\mathrm{P}<0.001)$ with knowledge of breast self-examination (BSE) (Table7). On the other hand, the age was variable found to have a significant correlation $(\mathrm{P}<0.02)$ with knowledge of clinical breast examination (CBE) (Table8). This could be explained by the limited mammography services and information. This finding is really similar to study conducted in Turkey found that the majority of the women had no knowledge about mammography [24].

The low levels of education in majority of the women who participated in the current study are another reason, in that the women may not know how to access accurate information about breast cancer. Like the study conducted in Turkey showed that majority $77.6 \%$ of the participants did not know the age range when mammography should be done nor did they know its potential in detecting early breast cancer [24]. Regarding breast ultrasound, only $7.2 \%$ of the participants thought that it is a method for early detecting breast cancer (Table4). This striking finding is contrary to study conducted in Turkey [24], but it is similar to study conducted in Uganda [25]. Regarding the aspect of practicing breast self-examination (BSE), the current study revealed that $45.4 \%$ of the participants were performed breast self-examination (BSE), only $32.5 \%$ regularly (Table5). In other studies, the percentage of monthly breast self-examination (BSE) have been found to be $32.1 \%$ among under graduated students in Nigeria[26] , 66\% among nursing students in Saudi Arabia[27]. 52\% among Jordanian nurses, and 38.7\% among Jordanian nursing students [28], and 36.7\% among selected female university students in Malaysia [29]. In the current study the participants were have no symptoms and lack of knowledge about how to do BSE were regarded as the barriers of not practicing breast self-examination (BSE) $(44.7 \%, 55.3 \%)$ respectively (Table5). these findings are similar to findings among Malaysian, Women [29]. Lack of knowledge about how to perform breast self-examination (BSE) among participant's women might have been due to insufficient education programs for breast health awareness. Breast health awareness provides women with some knowledge of the part they can play in being empowered to fight breast disease [30].

The practice of clinical breast examination (CBE) by physician was the second step in breast screening program [31].American cancer society has recommended clinical breast examination (CBE) for women aged 20 years once every two years and at age 40 annually. In our studies $40.2 \%$ of participants were examined clinically and $59.8 \%$ were never tried clinical breast examination (CBE). However, the most common reason for not practice clinical breast examination (CBE) were the fear of the outcome and no sign \& symptom of breast cancer $28.8 \%, 61.9 \%$ respectively (Table6). Similarly, study conducted in Vietnams found that the annual clinical breast examination (CBE) percentage was $45 \%$ in educated women [32]. This percentage was higher than the finding that reported in Iranian women in another studies [33]. On the other hand, this finding is lower than the study of $\mathrm{Wu} \mathrm{TY}$ and his coauthor in (2006) the study showed that $59 \%$ of educated Asian immigrants, who living in the US performed clinical breast examination (CBE) annually [34]. The implication of all of these is poor knowledge toward method of early detection of breast cancer.

\subsection{Limitation or weaknesses of the study}

Our study has some limitation as well given the social and cultural circumstance; some women in our study might have hesitated to speak openly about breast cancer to a stranger, even though some of the advantages of face-to-face such as : accurate screening of question, capturing verbal and non-verbal questions, keeping the interviewee focused on track to capture emotion and behaviors, the approach may lead to many limitation like the quality of data by interviewer, manual data entry and limited sample size.

\section{CONCLUSION}

The present study found the facts to the effect of inadequate knowledge of females on breast cancer prevalence and recognizes the negative influence of low knowledge on the practice of BSE, CBE and mammography.

\section{ACKNOWLEDGMENTS}

I would like to express my great thanks to the management, staff and nursing Maternity Teaching Hospital and all the staff for their excellent technical assistance and data collection.

\section{REFERENCE}

[1] A. Sadjadi, M. Nouraie, A. Ghorbani, M. Alimohammadian, and R. Malekzadeh, 
"Epidemiology of breast cancer in the Islamic Republic of Iran: first results from a populationbased cancer registry," 2009.

[2] F. Bray, P. McCarron, and D. M. Parkin, "The changing global patterns of female breast cancer incidence and mortality," Breast Cancer Research, vol. 6, p. 229, 2004.

[3] D. Parkin, S. Whelan, J. Ferlay, L. Raymond, and J. Young, "Cancer incidence in five continents. International Agency for Research on Cancer, Lyon: Vol. VII," ed: IARC Scientific publications, 1997.

[4] A. Jemal, M. M. Center, C. DeSantis, and E. M. Ward, "Global patterns of cancer incidence and mortality rates and trends," Cancer Epidemiology and Prevention Biomarkers, vol. 19, pp. 18931907, 2010.

[5] K. Hajian Tilaki, A. Firozjaii, and M. Kia, "Pattern of age distribution of different cancers in Babol," $J$ Res Med, vol. 27, pp. 239-45, 2001.

[6] A. Ramirez, A. Westcombe, C. Burgess, S. Sutton, P. Littlejohns, and M. Richards, "Factors predicting delayed presentation of symptomatic breast cancer: a systematic review," The Lancet, vol. 353, pp. 1127-1131, 1999.

[7] M. Richards, A. Westcombe, S. Love, P. Littlejohns, and A. Ramirez, "Influence of delay on survival in patients with breast cancer: a systematic review," The Lancet, vol. 353, pp. 1119-1126, 1999.

[8] O. O. T. O. Odusanya, Olumuyiwa, "Breast cancer knowledge, attitudes and practice among nurses in Lagos, Nigeria," Acta Oncologica, vol. 40, pp. 844848, 2001.

[9] C. J. Maxwell, C. M. Bancej, and J. Snider, "Predictors of mammography use among Canadian women aged 50-69: findings from the 1996/97 National Population Health Survey," Canadian Medical Association Journal, vol. 164, pp. 329334, 2001

[10] J. Philip, W. G. Harris, C. Flaherty, and C. A. F. Joslin, "Clinical measures to assess the practice and efficiency of breast self-examination," Cancer, vol. 58, pp. 973-977, 1986.

[11] M. Montella, A. Crispo, G. D'aiuto, M. De Marco, G. De Bellis, G. Fabbrocini, et al., "Determinant factors for diagnostic delay in operable breast cancer patients," European journal of cancer prevention, vol. 10, pp. 53-59, 2001.

[12] N. C. Facione, C. Miaskowski, M. J. Dodd, and S. M. Paul, "The self-reported likelihood of patient delay in breast cancer: new thoughts for early detection," Preventive medicine, vol. 34, pp. 397407, 2002.
[13] A. Hamdoon," Appraisal of breast self-examination in early detection of breast tumor". In Community Medicine department. Mosul University/ Iraq Press,pp 31-5,1996.Master thesis.

[14] T. T. Amin, A. Al Mulhim, and A. Al Meqihwi, "Breast cancer knowledge, risk factors and screening among adult Saudi women in a primary health care setting," Asian Pac J Cancer Prev, vol. 10, pp. 133-8, 2009.

[15] C. A. Adebamowo and O. Ajayi, "Breast cancer in Nigeria," West African journal of medicine, vol. 19, pp. 179-191, 2000.

[16] O. Odusanya, "Breast cancer: knowledge, attitudes, and practices of female schoolteachers in Lagos, Nigeria," The breast journal, vol. 7, pp. 171-175, 2001.

[17] C. A. Adebamowo and O. Ajayi, "Breast cancer in Nigeria," West African journal of medicine, vol. 19, pp. 179-191, 2000.

[18] A. McTiernan, "Behavioral risk factors in breast cancer: can risk be modified?," The oncologist, vol. 8, pp. 326-334, 2003.

[19] E. Uche, "Cancer awareness among a Nigerian population," Tropical doctor, vol. 29, pp. 39-40, 1999.

[20] W. Petro-Nustus and B. I. Mikhail, "Factors Associated with Breast Self-Examination Among Jordanian Women," Public Health Nursing, vol. 19, pp. 263-271, 2002.

[21] R. Visvanathan," Breast cancer in Nigeria women". British Journal of Surgery,vol.80,pp.126-209,1993.

[22] M. Haji-Mahmoodi, A. Montazeri, S. Jarvandi, M. Ebrahimi, S. Haghighat, and I. Harirchi, "Breast Self-Examination: Knowledge, Attitudes, and Practices Among Female Health Care Workers in Tehran, Iran," The breast journal, vol. 8, pp. 222$225,2002$.

[23] R. C. Katz, K. Meyers, and J. Walls, "Cancer awareness and self-examination practices in young men and women," Journal of behavioral medicine, vol. 18, pp. 377-384, 1995.

[24] A. Yücel, B. DEĞİRMENCI, M. Acar, H. Ellidokuz, R. Albayrak, and A. Haktanir, "Knowledge about breast cancer and mammography in breast cancer screening among women awaiting mammography," Turkish Journal of Medical Sciences, vol. 35, pp. 35-42, 2005.

[25] M. A. Gonzaga, E. Kiguli-Malwadde, B. Francis, and B. Rosemary, "Current knowledge, attitudes and practices of expectant women toward routine sonography in pregnancy at Naguru health centre, Uganda," The Pan African medical journal, vol. 3, 2009. 
[26] U. Gwarzo, K. Sabitu, and S. Idris, "Knowledge and practice of breast self-examination among female undergraduate students," Annals of African medicine, vol. 8, 2009.

[27] A. A. Alsaif, "Breast self-examination among Saudi female nursing students in Saudi Arabia," Saudi Med J, vol. 25, pp. 1574-8, 2004.

[28] N. Jaradeen, "Breast cancer risk-factors and breast self- examination practice among Jordanian women," Bahrain Medical Bulletin, vol. 32, pp. 17, 2010

[29] R. A. Al-Naggar, D. H. Al-Naggar, Y. V. Bobryshev, R. Chen, and A. Assabri, "Practice and barriers toward breast self-examination among young Malaysian women," Asian Pac J Cancer Prev, vol. 12, pp. 1173-1178, 2011.

[30] WA. Milaat," Knowledge of secondary school students on breast cancer and BSE in Jeddah, Saudi Arabia". Eastern Mediterranean Health Journal, vol. 6, pp.338-343, 2000.

[31] G. R. Sadler, C. M. Ko, J. A. Cohn, M. White, R.-n. Weldon, and $\mathrm{P}$. Wu, "Breast cancer knowledge, attitudes, and screening behaviors among African American women: the Black cosmetologists promoting health program," $B M C$ public health, vol. 7, p. 57, 2007.

[32] V. Ho, J. M. Yamal, E. N. Atkinson, K. BasenEngquist, G. Tortolero-Luna, and M. Follen, "Predictors of breast and cervical screening in Vietnamese women in Harris County, Houston, Texas," Cancer nursing, vol. 28, pp. 119-129, 2005.

[33] P. Yavari and M. A. Pourhoseingholi, "Socioeconomic factors association with knowledge and practice of breast self-examination among Iranian women," Asian Pac J Cancer Prev, vol. 8, pp. 618-22, 2007.

[34] S. SalimiPormehr, N. Kariman, Z. Sheykhan, and H. AlaviMajd, "Investigation of breast cancer screening tests performance and affecting factors in women referred to Ardebil's health and medical centers, 2009," Journal of Ardabil University of medical sciences, vol. 10, pp. 310-318, 2010.

[35] T.-Y. Wu, B. West, Y.-W. Chen, and C. Hergert, "Health beliefs and practices related to breast cancer screening in Filipino, Chinese and AsianIndian women," Cancer Detection and Prevention, vol. 30, pp. 58-66, 2006. 